\section{PORTUGAL, ESPAÑA Y EL FÚTBOL. LA CONSTRUCCIÓN HISTÓRICA DE UNA AMISTAD}

\section{Francisco Pinheiro}

Centro de investigação: CEIS20 - Centro de Estudos Interdisciplinares do Século XX, Universidade de Coimbra, Portugal franciscopinheiro72@gmail.com

Cómo citar este artículo/Citation: Pinheiro, F. (2014). “Portugal, España y el fútbol. La construcción histórica de una amistad". Arbor, 190 (766): a117. doi: http://dx.doi. org/10.3989/arbor.2014.766n2009

Recibido: 11 septiembre 2012. Aceptado: 27 noviembre 2013.

RESUMEN: El fútbol es uno de los principales fenómenos sociales y culturales en Portugal y España, habiendo creado importantes puentes de amistad entre los dos países en el siglo XX. Este artículo tiene como objetivo identificar los motivos que llevaron a la construcción histórica de esta relación ibérica en el fútbol, exponiendo algunos de los principales momentos que permitieron crear esta amistad. El análisis se centra en la primera mitad del siglo XX, periodo en el cual nació, creció y se desarrolló esta relación.

\section{PORTUGAL, SPAIN AND FOOTBALL. THE HISTORICAL CONSTRUCTION OF A FRIENDSHIP}

Copyright: (C) 2014 CSIC. Este es un artículo de acceso abierto distribuido bajo los términos de la licencia Creative Commons Attribution-Non Commercial (by-nc) Spain 3.0.
ABSTRACT: Football is one of the most important social and cultural phenomena in Portugal and Spain, responsible for building solid ties of friendship between the two countries in the 20th century. This article aims to identify the reasons for the emergence of this Pan-Iberian relationship in football, focusing on how the friendship developed and became established over the first half of the 20th Century. 


\section{INTRODUÇÃO}

No dia 2 de Dezembro de 2010, em Zurique, o presidente da FIFA, Joseph Blatter, anunciou o resultado das votações do Comité Executivo daquele organismo para as candidaturas à organização dos Campeonatos do Mundo de Futebol de 2018 e 2022. A candidatura ibérica, de Espanha e Portugal, ficou em segundo lugar, preterida a favor da Rússia, para a organização do Mundial de 2018. Apesar da natural desilusão, a candidatura ibérica foi, em si mesma, uma demonstração das boas relações desportivas e políticas existentes entre ambos países. É precisamente sobre a construção histórica desta relação ibérica no futebol que irá versar esta reflexão, pincelando alguns dos principais momentos que permitiram arquitectar esta amizade ibérica num campo tão específico como o futebolístico, cingindo-se a análise à primeira metade do século $X X$, período durante o qual nasceu, cresceu e se consolidou esta relação. $O$ objecto de estudo será assim o futebol, nas suas múltiplas dimensões, além da meramente desportiva.

O futebol transformou-se, ao longo do século XX, numa das maiores paixões populares nos dois países, ocupando um lugar central em ambas sociedades e assumindo-se, sem dúvida, num dos temas preferidos das conversas, dominando os discursos mediáticos e as audiências em Portugal e Espanha. E em certos momentos conseguiu mesmo parar os países, tornando-os mais felizes ou deprimidos conforme os resultados dos jogos, em especial das suas selecções nacionais. Aliás, a condição de centralidade social e cultural do futebol, em Portugal e Espanha, permite claramente aplicar a este fenómeno o conceito de "facto social total» (Coelho, 2001, 38), o qual Marcel Mauss definiu como "fenómenos que em certos casos mobilizam a totalidade da sociedade e das suas instituições» (Bromberger, 1993, 145). Foi precisamente isso que sucedeu em Portugal durante a realização do Campeonato da Europa de Futebol de 2004, em 2010, na Espanha, com a conquista do Campeonato do Mundo de Futebol da África do Sul. Deste modo, o futebol, em si mesmo, diz-nos muito acerca de cada um dos dois países, merecendo por isso toda a atenção por parte das ciências sociais e humanas.

\section{INTERNACIONALIZAÇÃO PELA MÃO ESPANHOLA}

Os primórdios do futebol em Portugal remontam ao último quartel do século XIX, estando a sua origem ligada às elites portuguesas que estudavam em Inglaterra, em colégios ingleses (onde a modalidade nascera e se popularizara), e à comunidade inglesa radicada em Portugal, principalmente nos meios urbanos de Lisboa e Porto. Entre 1888 e os primeiros anos da década de 1900 assistiu-se à «fase de descoberta» (Coelho; Pinheiro, 2004b, 33) do futebol por parte dos portugueses, verificando-se a partir de meados dessa década um processo de crescente popularização e institucionalização da modalidade. Para o despoletar desse fenómeno foi essencial o papel da imprensa desportiva, assim como a organização dos primeiros torneios e a fundação daqueles que viriam a ser os clubes portugueses mais populares, denominados de "três grandes", como seriam o Sport Lisboa e Benfica (Lisboa, 1904), Sporting Clube de Portugal (Lisboa, 1906) e Futebol Clube do Porto (Porto, 1906). A conjugação destes factores permitiu ao futebol abandonar o berço de ouro das elites, em que nascera no século XIX, e caminhar rapidamente para os braços do povo, tornando-se progressivamente num fenómeno de massas.

A gradual popularização do futebol em Portugal, na primeira década do século $X X$, levaria as principais equipas de Lisboa e do Porto a procurarem internacionalizar-se, podendo assim comparar o nível do seu futebol com o das equipas estrangeiras. E numa época em que os meios de transporte eram escassos e muito morosas as viagens foi com naturalidade que se iniciaram os primeiros contactos com equipas da vizinha Espanha. A primeira visita de um clube português a Espanha sucedeu em inícios de 1907, com o Clube Internacional de Futebol, mais conhecido por CIF (fundado pela elite lisboeta), a visitar Madrid, a convite de um clube da capital madrilena. Uma vez que se desconhecia o nível qualitativo do futebol espanhol, a equipa portuguesa reforçou-se com alguns dos melhores jogadores de outras equipas lisboetas e, inclusivamente, do Porto. Assim, no dia 5 de Janeiro, perante cerca de dez mil espectadores, o CIF enfrentou os anfitriões do Madrid Football Club, conseguindo impressionar o público espanhol com uma exibição que valeu uma vitória lusa por 2-0. A imprensa portuguesa, através da revista Tiro e Sport (Lisboa, 19041913), faria eco da forma amistosa com que a equipa portuguesa foi recebida em Madrid, sendo a recepção espanhola considerada exemplar, envolvendo várias actividades sociais e festivas, como idas ao teatro e lautos banquetes.

O sucesso deste primeiro intercâmbio ibérico gerou uma onda de simpatia na imprensa desportiva portuguesa, incentivando as principais equipas lusas a fazerem a sua estreia internacional com clubes espa- 
nhóis. No Norte, o FC Porto estabeleceu contacto com alguns clubes da Galiza, convidando-os a visitarem o Porto. Uma equipa de Vigo, o Fortuna Football Club, aceitou o convite e em Dezembro de 1907 deslocouse ao Porto, onde enfrentou a equipa portista, naquele que seria considerado o primeiro jogo internacional de um clube estrangeiro em Portugal (Coelho \& Pinheiro, 2002, 109). Mais uma vez repetiram-se as imagens de amizade e simpatia entre ambos clubes, contribuindo decisivamente para a criação daquele que seria um dos elos mais fortes do futebol ibérico ao longo da primeira metade do século $\mathrm{XX}$, formado pelas regiões da Galiza e do Norte de Portugal, em especial entre as cidades do Porto e Vigo. Esta relação de proximidade levaria mesmo, em inícios de 1909, o Vigo Football Club a promover a organização de um Concurso Ibérico de Futebol, prova que deveria ser disputada entre Janeiro e Fevereiro de 1909, tendo como prémio uma taça em prata. As equipas escolhidas teriam de pertencer à Península Ibérica e deveriam representar uma região. Em Portugal, a revista Tiro e Sport apoiaria a ideia na edição de 10 de Janeiro de 1909, sublinhando a importância do torneio para o desenvolvimento do futebol ibérico e para o reforço das relações desportivas entre ambos países. Mas, apesar da receptividade da imprensa portuguesa, o concurso não avançaria devido às dificuldades impostas pela falta de meios de transporte entre as regiões e pela ausência de órgãos associativos e federativos que garantissem uma boa organização.

Apesar da tentativa frustrada de organizar o primeiro torneio ibérico de futebol, os convites interclubes continuaram a suceder-se. Em Maio de 1909, o CIF, que tão boa imagem havia deixado em Madrid em 1907, recebeu um novo convite para jogar em Espanha, desta feita pelo Sport Club Bacense, de Badajoz. O grande atractivo para os portugueses era a possibilidade de conquistar uma magnífica taça oferecida pela autarquia de Badajoz, que se associou à iniciativa. Deste modo, em 13 de Maio de 1909, perante uma multidão de quatro mil pessoas, a equipa do CIF demonstraria a sua classe em terras extremenhas, impressionando o público espanhol pela sua técnica e capacidade física, vencendo por um claro 3-0. A imagem do CIF ficaria, desta forma, ainda mais fortalecida em Espanha, trazendo de Badajoz a primeira taça conquistada no estrangeiro por uma equipa de futebol portuguesa. E, naturalmente, o prestígio granjeado pelo CIF motivaria novos convites em 1910. Em meados desse ano, o Club Recreativo de Huelva endereçou um convite à equipa lisboeta para um jogo amigável, tendo o CIF declinado o apelo, apontando o Sporting CP como uma opção para o substituir. Embora a vontade de jogar pela primeira vez contra uma equipa estrangeira fosse muita, o clube sportinguista teve dificuldades em reunir jogadores suficientes e de qualidade para a viagem a Huelva, decidindo-se pela formação de um misto dos melhores jogadores lisboetas. Este misto jogou a Huelva em 27 de Agosto de 1910, goleando o Recreativo por 4-0, perante mais de oito mil espectadores, uma assistência numerosa com forte presença de mulheres e crianças. No final do jogo celebrou-se um animado banquete de homenagem à equipa portuguesa, findo o qual os portugueses encetaram a viagem de regresso a Lisboa, que demoraria cerca de 26 horas, envolvendo percursos de carro e comboio.

A implantação da República Portuguesa, em 5 de Outubro de 1910, ditando o fim do regime monárquico, motivaria algumas tentativas de mudança de mentalidades, com efeitos a nível desportivo. A ideia de desporto enquadrava-se agora no princípio de regeneração, robustecimento e criação do «novo» homem português, afastando-se da decadência associada à Monarquia e ao "velho» homem monárquico, apresentado na imprensa desportiva como corrupto, retrógrado e mais interessado na taberna do que na actividade física. Nos primeiros anos da República, entre 1910 e 1913, a popularidade do futebol cresceu, ultrapassando em fama outros desportos e espectáculos até aí preferidos pelo povo, como eram as touradas ou o ciclismo.

Neste período reforçou-se a ligação futebolística entre o Norte de Portugal e a Galiza, com as principais equipas do Porto e Vigo a visitarem-se regularmente. A boa relação entre ambas regiões estaria na origem da digressão pela Corunha e pelo Porto, em Abril de 1911, da equipa francesa do Vie au Grand Air du Medoc, de Bordéus, campeã do sudeste da França. No mês seguinte, por seu turno, Lisboa assistiu entusiasticamente à visita do primeiro clube estrangeiro de futebol, os franceses do Stade Bordelais Université Club. Estas visitas de clubes estrangeiros, alargadas agora ao meio desportivo francês, contribuíram largamente para a popularização do futebol em Portugal, atraindo milhares de espectadores, quer pela novidade quer pelo despertar de sentimentos patrióticos, muito em voga na época. E além de terem como objectivo melhorar o nível futebolístico dos portugueses, eram também parte integrante de uma política de reconhecimento internacional do novo regime republicano. Este período marcou um grande desenvolvimento da modalidade, correspondendo a uma segunda fase de 
estruturação do futebol português, agora virada para o movimento associativo (Coelho \& Pinheiro, 2004b, 38), formando-se as associações regionais de futebol de Lisboa (1910), Portalegre (1911), Porto (1912), assim como a União Portuguesa de Futebol (1914), primeiro órgão nacional de futebol (em 1926 seria convertida em Federação Portuguesa de Futebol).

Prosseguindo a tendência de 1911, no ano seguinte realizaram-se vários jogos internacionais entre clubes portugueses e espanhóis. Em Março, o Real Vigo visitou a cidade do Porto, efectuando alguns encontros, o mais importante deles frente ao FC Porto, em 17 de Março, no Campo da Rainha, com a equipa portuense a vencer por 4-1, perante numeroso público, angariando uma receita de bilheteira histórica. Pouco tempo depois, em Junho, seria a vez do SL Benfica visitar a Corunha, naquela que era a sua primeira digressão ao estrangeiro, a convite do Real Clube da Corunha. Estes encontros internacionais continuaram, assim, a reforçar a amizade ibérica no futebol, contribuindo para o desenvolvimento técnico e táctico do futebol português, bem como para a criação de uma mentalidade desportiva mais forte por parte dos futebolistas portugueses. E obviamente os jogos entre equipas portuguesas e espanholas mantiveram-se no ano seguinte, em 1913, sublinhando-se a visita a Madrid do SL Benfica e do CIF, ambas convidadas pelo Madrid Football Club e pela Sociedad Gimnastica de Madrid.

\section{GUERRA REFORÇA AMIZADE IBÉRICA}

Entre 1914 e 1918, o desenrolar da Primeira Guerra Mundial contribuiu para uma maior aproximação entre o futebol português e espanhol. A imprensa desportiva portuguesa, escassa e confinada a Lisboa, publicava regularmente editoriais que defendiam uma crescente aproximação entre Portugal e Espanha no campo desportivo. Com o som das armas a dominar os diálogos entre as principais potências europeias, era aplaudido o aprofundamento das relações entre os dois vizinhos ibéricos. Em 17 de Abril de 1915, no artigo «E a Espanha?», o principal jornal desportivo português, O Sport de Lisboa (Lisboa, 1915-1934), lembrava que os países mais desconhecidos para os portugueses eram aqueles a que estes estavam historicamente mais unidos: "Os dois países a que nós estamos, há séculos, mais intimamente ligados são a Inglaterra e a Espanha - aquela, nossa aliada, esta, nossa vizinha. São justamente, de todo o globo terráqueo, os países que nós menos conhecemos. Não admira, pois, que a arte, a literatura, a ciência, a indústria, o comércio espanhóis nos sejam absolutamente desconhecidos. Naturalmente o mesmo sucede no campo dos desportos. Desconhecemo-nos e desconhecemo-nos mutuamente.»

Apesar desse desconhecimento mútuo, o campo futebolístico continuou a criar pontes entre ambos países durante os anos da guerra. Em 1915, os convites sucederam-se de lado a lado. O SL Benfica realizou uma digressão por Espanha, efectuando vários jogos em Madrid (onde venceu o Real Madrid por 5-4) e na Galiza. E em meados desse ano, Real Vigo e Real Club Deportivo Español, de Barcelona, visitaram Lisboa a convite dos principais clubes da capital portuguesa, repetindo-se o ambiente de amizade reinante até então nestas partidas. Mas algo estava a mudar. Começou a notar-se um crescendo de competitividade entre as equipas, com o espírito de vitória a começar a sobrepor-se à tradicional ideia de fair-play.

A entrada de Portugal na guerra, em 1916, afectou todos os campos sociais, com o mundo do futebol a ficar debilitado com a saída de muitos jogadores para ingressarem nas fileiras do Corpo Expedicionário Português, criado especificamente para participar no conflito ao lado dos Aliados. No entanto, o futebol não parou, continuando a realizarem-se os campeonatos regionais, assim como as visitas de clubes espanhóis, embora em menor escala. Em inícios de Junho de 1918, o Sevilla FC visitou Lisboa a convite dos principais clubes da cidade, realizando uma série de jogos, assistindo-se mais uma vez a uma grande adesão por parte do público lisboeta, com assistências de largos milhares de espectadores.

Esta aproximação entre o futebol de ambos países, durante a guerra, permitiria o surgimento de ideias que visavam o reforço da amizade ibérica no futebol. Uma das principais ambições era a realização do primeiro encontro entre selecções nacionais representativas dos dois países, ideia lançada em 1919 pela imprensa desportiva portuguesa e espanhola - notese que nesta altura nenhum dos países contava com uma selecção nacional de futebol e a ideia de cada um dos países criar a sua selecção, estreando-se juntas, recebia consensos. A necessidade de reforçar os laços ibéricos era reflexo da própria conjuntura política, dominada em parte, no caso português, pelo movimento que ficaria conhecido como Integralismo Lusitano ${ }^{1}$, defensor de uma «aliança peninsular» e caracterizado por um vasto conjunto de ideias conservadoras e monárquicas, o qual proliferou na sociedade portuguesa entre 1919 e 1922. 


\section{FENÓMENO CHAMADO SELECÇÃO NACIONAL}

Estes movimentos políticos tiveram óbvios reflexos no desporto português, sobretudo na imprensa desportiva, que ao longo dos anos havia apelado a uma maior aproximação entre os dois países, apresentando como prejudicial a tradicional separação em que ambos países haviam vivido ao longo da história. Um dos melhores exemplos dessa retórica desportiva de aproximação peninsular foi o editorial «Sport e boa política», publicado em Os Sports (Lisboa, 1919-1945) de 21 de Novembro de 1920, em que se afirmava: «Nós ignoramos a Espanha e Espanha desconhece Portugal. Vivemos lado a lado em regime de permanente desconfiança. A ciência, a arte e a cultura espanholas pouco ou nada nos interessa e poucos são entre nós os que dão conta dos congressos realizados em Espanha sobre a agricultura e a indústria. Ignoramos mesmo a estrutura moral dos nossos vizinhos. Julgamo-la diferente da nossa. Imputamos-lhe vícios e defeitos de que enfermamos também em larga escala. Muito melhor, e bem diferente da actual seria a vida peninsular se entre os dois países houvesse amistosas relações de intimidade, com a consequente troca intensiva de ideias em todos os campos.» A aproximação luso-espanhola chegou mesmo a ser apresentada na imprensa desportiva como a segunda prioridade para a política portuguesa, logo a seguir ao reforço das relações com o Brasil, como escreveria O Sport de Lisboa de 19 de Dezembro de 1921: «Nós somos partidários fervorosos da aproximação entre povos que têm pontos de contacto entre si. Somos, em primeiro lugar, pela aproximação luso-brasileira e, em segundo, pela aproximação luso-espanhola.»

Foi neste contexto favorável à aproximação lusoespanhola que durante 1920 se intensificaram os contactos entre ambas federações para a realização do primeiro jogo entre as selecções nacionais de futebol dos dois países. E esperava-se que os problemas económicos surgidos em 1912, altura em que se tentou pela primeira vez levar a cabo o jogo entre as duas selecções, não surgissem novamente. Para Portugal tratava-se da estreia. Espanha, por seu lado, havia-se estreado durante a participação nos Jogos Olímpicos de Antuérpia de 1920, na Bélgica, onde alcançou a medalha de prata. Desta feita, as negociações entre os dirigentes máximos do futebol dos dois países chegariam a bom porto, agendando-se o primeiro PortugalEspanha para Maio de 1921, em Madrid. No entanto, dificuldades de vária ordem obrigariam a um adiamento da partida, até que a 20 de Agosto se anunciou nova data, agora definitiva: 18 de Dezembro de 1921.
Na imprensa desportiva portuguesa, a deslocação a Espanha da primeira Selecção Nacional de Futebol de Portugal era vista com algum receio do ponto de vista desportivo. O futebol português continuava sem uma prova regular de cariz nacional, embora fosse uma aspiração antiga da União Portuguesa de Futebol. Em 1921, a maioria dos países europeus já possuía um campeonato nacional, fundamental para o desenvolvimento dos clubes e do próprio futebol. Espanha contava desde 1902 com uma prova deste género. Em Portugal, eram muitos os clubes existentes, as associações regionais activas, sucedendo-se os campeonatos regionais e os jogos particulares, mas faltava uma competição organizada, calendarizada, com representatividade nacional, que permitisse aos clubes gerar receitas para investir em melhores instalações desportivas (a maioria dos campos eram pelados, sem condições para os jogadores e público) e na qualidade do treino (o amadorismo era dominante). Durante 1921, as digressões de duas das principais equipas portuguesas por Espanha tinham-se saldado com sendas derrotas, denotando um claro domínio do futebol espanhol sobre o português. Em Março, o FC Porto perdeu os dois jogos que realizou na capital espanhola contra o Real Madrid, conseguindo unicamente um empate contra o Club Deportivo Europa, de Barcelona. E em Setembro, o SL Benfica foi goleado nos dois encontros que disputou na Catalunha contra o FC Barcelona.

Além do desequilíbrio competitivo que aparentemente existia entre o futebol dos dois países, a escolha dos jogadores portugueses para integrarem a primeira Selecção Nacional também não foi pacífica, gerando controvérsia a não convocação daquele que era considerado o melhor jogador português das duas primeiras décadas do século $X X$, o médio Artur José Pereira, mais conhecido como "AJ Pereira». A convocatória levaria também as duas principais associações de futebol, Lisboa e Porto, a desentenderem-se, com a imprensa portuense a chamar de "Selecção de Lisboa» à Selecção Nacional, uma vez que apenas estava convocado um futebolista que actuava no Campeonato do Porto.

Apesar das polémicas, que viriam a ser recorrentes ao longo da história da Selecção Nacional de Futebol, a comitiva portuguesa partiu de Lisboa, rumo a Madrid, em 14 de Dezembro, sendo consensual na imprensa que os seleccionados não representavam o valor máximo do futebol português, como se lia no jornal Os Sports de 15 de Dezembro de 1921. A equipa portuguesa chegou à capital espanhola na madrugada 
fria do dia 15, aguardando-a alguns jornalistas e fotógrafos espanhóis. O campo escolhido para o encontro foi o do Atlético de Madrid, em terra batida, estreito e com bancadas totalmente descobertas, apresentando também algum desnível. E para agravar a situação, os dirigentes espanhóis impediram a Selecção Portuguesa de treinar no campo, alegando a necessidade de o conservar intacto para o jogo. Embora esta situação tivesse causado algum mal-estar na comitiva lusa, foi num contexto de grande euforia e amizade que na tarde de 18 de Dezembro de 1921, em Madrid, a Selecção Nacional de Futebol Portuguesa se estreou frente à congénere espanhola, numa partida dominada pelos espanhóis, dotados de uma qualidade técnica e táctica superiores. Apesar da boa réplica dada pelos jogadores portugueses, Espanha venceu por 3-1, resultado natural devido ao défice qualitativo do onze luso quando comparado com o espanhol.

A derrota trouxe consigo, para as páginas dos jornais desportivos, muitos dos fantasmas que atormentavam o espírito nacional, sendo o futebol apresentado como um reflexo do resto da sociedade portuguesa, como afirmaria o jornal Os Sports em 15 de Janeiro de 1922: "Portugal, há mais de 50 anos que se mantém afastado do resto da Europa, não sabendo acompanhar o colossal movimento de renovação e de transformação que se realizou e se está continuamente realizando em todos os ramos da actividade humana. O problema, pois, apresenta-se muito claro. De duas, uma: ou mudamos completamente de processos e nos resolvemos, por uma vez, a compreender que nada se consegue sem muito trabalho, ou continuamos persistindo nos mesmos erros e nos mesmos defeitos.»

Nos dois anos seguintes, as derrotas de Portugal com a selecção espanhola continuaram e cada uma delas terminava, nas páginas da imprensa desportiva e na opinião pública, numa introspecção sobre a identidade nacional, em que a política portuguesa era normalmente a visada, como sucedeu após o desaire por 0-3, no terceiro jogo frente a Espanha, realizado em Sevilha, em 16 de Dezembro de 1923. Dias depois, em 26 de Dezembro, nas páginas da revista Sporting (Porto, 1921-1953), um dos mais prestigiados cronistas desportivos da época, Sousa Martins, a propósito da derrota portuguesa, afirmava que «a política portuguesa é a mais baixa, a mais reles, a mais ignóbil de toda a Europa, porque não há país nenhum no mundo, onde à sombra da política, tantos crimes impunemente se cometam». O futebol era assim o pretexto para se reflectir sobre os males que afectavam Portugal, com as derrotas da Selecção Nacional a serem encaradas como autênticos desaires nacionais e exemplos da decadência reinante. Mas quando sucedia uma vitória, escassas nos anos 1920, era vista como uma autêntica afirmação de regeneração nacional - a dicotomia decadência/regeneração, em que vivia a ideia de Portugal, dominava também o mundo da bola.

Além dos reflexos ideológicos, as derrotas com Espanha tiveram também efeitos práticos. O primeiro aconteceu logo em inícios de 1922, após a derrota no jogo de estreia em Madrid. Como forma de acalmar as duras críticas à União Portuguesa de Futebol, órgão máximo do futebol português, esta decidiu avançar com a realização de uma competição de cariz nacional, o Campeonato de Portugal. Mas as dificuldades organizativas inerentes a uma prova do género determinaram que em 1922 fosse apenas disputada pelos vencedores dos campeonatos regionais de Lisboa e Porto, deixando de fora outros campeões regionais, o que gerou forte indignação a nível regional. A derrota com Espanha nesse ano, em 17 de Dezembro de 1922, em Lisboa, naquele que foi o primeiro jogo da Selecção de Portugal em território nacional (perante 25 mil pessoas), e a derrota do ano seguinte, em Sevilha, gerariam novas e profundas reflexões sobre o futebol português, motivando a reformulação do Campeonato de Portugal de forma a transformá-lo numa competição de maior regularidade e de cariz nacional. 0 objectivo era melhorar o nível qualitativo das equipas portuguesas, que em 1922 sofreram pesadas derrotas frente a equipas espanholas, como sucedeu em Janeiro na digressão do SL Benfica a Sevilha (perdeu por 7-0 com o Sevilha FC) e a Madrid (derrota por 4-1 perante o Real Madrid), e em Dezembro ao FC Porto, goleado em Sevilha por 7-2. Esta superioridade dos clubes espanhóis iria manter-se ao longo da década de 1920, assim como se mantiveram as digressões de equipas espanholas e portuguesas pelos dois países, reflexo da amizade ibérica que existia no futebol. $E$ que seria reforçada na década seguinte com a amizade Franco-Salazar.

\section{FUTEBOL E FASCISMO}

O ano de 1926 seria de mudança política em Portugal, com implicações directas na vida desportiva. Chegou ao fim, de forma inglória, a I República, substituída em 28 de Maio de 1926, através de um golpe militar, por uma indefinida Ditadura Militar, a qual se transformaria numa ditadura civil (baptizada de Estado Novo) com a chegada ao poder do 
ditador Salazar, em 1932. Assim, o final da década de 1920 seria marcada por uma forte instabilidade e indefinição política, em que primou a ausência de uma perspectiva estratégica, com a sociedade portuguesa a afundar-se, uma vez mais, num pântano de incertezas e incógnitas, levando a novas e profundas introspecções na imprensa, quase sempre negativas, sobre a identidade nacional. Os editoriais dos jornais desportivos passaram a reflectir essa mesma indefinição, agravada com a imposição da Censura prévia à Imprensa. Mas era consensual entre os jornalistas desportivos que o dia-a-dia da imprensa desportiva não iria ser muito afectado pela Censura, já que o jornalismo desportivo não era considerado prioritário, nem ideologicamente perigoso, para o censor. $\mathrm{E}$ isso devia-se ao facto do regime ditatorial português não ter seguido o modelo desportivo adoptado por Mussolini e Hitler nos anos 1930, que cedo reconheceram no desporto um importante meio de propaganda, tratando de cuidar ao máximo da preparação dos atletas, fomentando a sua participação nos encontros desportivos internacionais (Teja, 2002, 241), e do controlo noticioso no campo desportivo.

A boa relação existente entre o futebol português e espanhol manteve-se nos primeiros anos da Ditadura Militar. As duas federações de futebol continuaram próximas, agendando inclusivamente um jogo amigável entre selecções em 29 de Maio de 1927, altura em que se comemorava o primeiro aniversário do regime ditatorial em Portugal. Os encontros amigáveis entre ambas selecções mantiveram-se regulares nos anos seguintes, com clara superioridade competitiva por parte de Espanha. E foi com alguma naturalidade que em 11 de Março de 1934, em Madrid, Portugal sofreu uma humilhante derrota por 9-0 contra a Espanha, no primeiro jogo de apuramento para o Mundial de 1934. Uma semana depois, no dia 18 , no jogo de volta, em Lisboa, nova derrota de Portugal, mas por números menos escandalosos (1-2).

A goleada e o consequente falhanço na qualificação para o Campeonato do Mundo de 1934, assim como a clara inferioridade competitiva em relação a Espanha, obrigaram os dirigentes portugueses a uma profunda reflexão sobre o futuro do futebol português. Se as vitórias traziam consigo rasgados elogios a Portugal e aos portugueses, as derrotas, quando pesadas, como foi o caso do 9-0, criavam verdadeiras ondas de contestação e exaltação. A mais importante revista ilustrada desportiva da década de 1930, a Stadium, publicou em 28 de Março de 1934 a crónica «Caso inédito, Inoportunas improvisações», onde sublinhava os efei- tos morais da goleada: "Apareceram uns exaltados patriotas que, numa confusão tremenda, condensaram numa só as sete cores do arco-íris a transbordar patriotismo às mãos cheias, de tal forma que, se não os conhecêssemos, tínhamo-nos alistado no primeiro regimento para combater os espanhóis. Aljubarrota, Alcácer-Quibir e todas as passagens guerreiras entre castelhanos e portugueses foram chamadas à tela por causa do desastre de Chamartin.»

A goleada frente a Espanha deixou patente a falta de qualidade técnica e táctica do futebol luso, confinado a lutas bairristas entre selecções regionais, aos campeonatos regionais e ao Campeonato de Portugal (prova a eliminar). Era notória a ausência de uma prova de regularidade de cariz verdadeiramente nacional. De forma a colmatar esta lacuna e para acalmar os ânimos exaltados com a humilhante derrota por 9-0, a Federação Portuguesa de Futebol (FPF) definiu para a época de 1934/35 a organização dos campeonatos da Liga da I e II Divisões, que viriam a ser um sucesso, quer a nível financeiro (as receitas dos clubes triplicaram), quer de popularidade. $\mathrm{O}$ aparecimento da rádio permitiu também uma maior difusão da modalidade, sendo pela primeira vez possível, a centenas de milhares de adeptos, acompanhar o espectáculo do futebol em directo e desde qualquer local, como sucedeu com o encontro amigável entre Portugal e Espanha, em 5 de Maio de 1935 (empate 3-3), realizado em Lisboa e transmitido radiofonicamente, pela primeira vez, para todo o País, Espanha, Canárias e Brasil. A rádio permitiu ao futebol cativar mais entusiastas, massificando a ideologia desportiva (futebolística) de uma forma até então inimaginável, com a rivalidade entre Portugal e Espanha a revestir especial atenção popular e informativa.

Nos anos seguintes, a Guerra Civil Espanhola (1936-1939) agravaria as dificuldades de passagem dos portugueses rumo ao resto da Europa e teria o condão de transformar a já tradicional «barreira dos Pirenéus ${ }^{2}$ num obstáculo ainda mais difícil de transpor. Mas esse muro psicológico dos Pirenéus, se por um lado dificultou as relações de Portugal com a Europa, serviu algumas vezes como uma espécie de tapume aos ventos trágicos e incertos vindos desse mesmo espaço europeu, como iria ocorrer durante a Segunda Guerra Mundial.

Face aos exemplos que vinham do estrangeiro, principalmente dos dois regimes totalitários de referência (Alemanha e Itália), era incontornável que a Selecção Nacional de Futebol Portuguesa entrasse gradualmente ao serviço da propaganda fascista durante os anos 
1930, principalmente para reforçar a ideia de «bloco ibérico» (Pinheiro, 2006, 170-175). Foi no âmbito da amizade de Salazar e Franco que, em 28 de Novembro de 1937, a equipa nacional portuguesa se deslocou a Vigo para enfrentar a Selecção de Espanha (ou melhor, uma selecção espanhola falangista ${ }^{3}$ ), naquele que foi o único jogo realizado pela Selecção Portuguesa nesse ano. O ambiente propagandístico foi cuidadosamente preparado: no estádio, atrás da tribuna central, foi erguida uma torre onde pendiam dois painéis com as imagens de Salazar e Franco. Coube à banda militar de Vigo tocar os hinos nacionais, durante os quais a multidão se conservou de braço estendido, fazendo a saudação fascista. E para encerrar a pequena cerimónia que antecedia o jogo, um legionário português ergueu a voz e gritou por três vezes as palavras Salazar, Franco, Espanha e Portugal, fazendo vivas no final aos dois países ${ }^{4}$. Só a FIFA recusou alinhar neste género de estratégia política, invalidando a partida (que os portugueses venceram por 2-1) devido à falta de legitimidade da equipa espanhola, composta unicamente por jogadores falangistas. Mas o sucesso político foi o desejado.

Dois meses depois, em 30 de Janeiro de 1938, em Lisboa, a selecção portuguesa recebeu mais uma vez a congénere espanhola, numa partida em que Portugal venceu novamente, por 1-0, mas que a FIFA voltaria a não reconhecer oficialmente devido à falta de legitimidade da equipa de Espanha. Para além disto, o jogo ficaria também marcado pela revolta de alguns jogadores portugueses. Como era habitual, nos momentos que antecediam o início das partidas, os futebolistas portugueses e os adversários saudavam a assistência com a tradicional saudação fascista, de braço direito bem esticado, ao alto, e mão aberta, no centro do terreno de jogo. Mas nesse dia três jogadores portugueses romperam o protocolo, furtandose à saudação fascista: dois deles (Mariano Amaro e José Simões) cerraram o punho e o outro (Artur Quaresma) nem sequer levantou o braço - na origem do acto estiveram desentendimentos entre os jogadores e a Federação Portuguesa de Futebol. A imprensa foi obrigada a silenciar o caso (a Censura a isso obrigava) e houve mesmo quem tentasse adulterar o momento, publicando fotografias retocadas de forma a parecer que os punhos cerrados afinal estavam abertos, como foi o caso da revista Stadium, na edição de 2 de Fevereiro de 1938. A indisciplina dos três jogadores não passou despercebida à Polícia de Vigilância e Defesa do Estado (PVDE, rebaptizada em 1945 como PIDE - Polícia Internacional e de Defesa do Estado), que deteve os três internacionais para averiguações no final do encontro, sob suspeitas de prática de «Cri- me contra a Nação». Simões e Amaro ficaram presos durante vários dias, mas o caso não teria maiores consequências, já que a polícia política não quis medir forças com a popularidade do futebol, além de que o Belenenses (clube onde os três actuavam) contava com pessoas politicamente bem colocadas e afectas ao regime. Poucas semanas depois, Amaro e Simões voltaram mesmo a envergar novamente a camisola da selecção portuguesa.

A amizade ibérica no futebol iria reforçar-se a partir de 1939 com o início da Segunda Guerra Mundial, que agravou o distanciamento português com outras convizinhas europeias, e com o fim da Guerra Civil de Espanha. O facto da beligerância portuguesa pouco interessar aos Aliados - mais preocupados em que Portugal conseguisse assegurar a neutralização da Península Ibérica, agarrando a Espanha franquista à ideia de neutralidade (Rosas, 1991, 125) -, levou o governo de Salazar, após consultar a velha aliada Inglaterra, a declarar a posição neutral de Portugal perante a guerra, o que sucedeu numa nota oficiosa emitida a 2 de Setembro de 1939 - Espanha faria o mesmo em 1942. Em termos futebolísticos, o conflito bélico teve efeitos negativos, uma vez que passou a impedir os contactos internacionais de clubes e selecção portugueses, forçando um reforço da amizade com Espanha.

Quadro 1. Países com quem Portugal realizou mais jogos particulares durante a Ditadura (Maio de 1926 a Abril 1974)

\begin{tabular}{|c|c|}
\hline Adversário & Total de Jogos \\
\hline Espanha & 18 \\
\hline França & 12 \\
\hline Inglaterra & 9 \\
\hline Brasil & 9 \\
\hline Itália & 8 \\
\hline Suiça & 7 \\
\hline
\end{tabular}


Com os Pirinéus a servirem como uma barreira física, e até psicológica, aos ventos de guerra que se abateram sobre toda a Europa entre 1939 e 1945, foi perfeitamente compreensível o fortalecimento do bloco ibérico também no futebol, o qual se iria manter durante todo o período ditatorial português (ver Quadro 1). O estreitamento das relações luso-espanholas seria uma das grandes prioridades da política salazarista durante o decorrer da Segunda Guerra Mundial, com Salazar e Franco a prosseguirem com essa mesma política nas décadas que se seguiram ao término do mais nefasto conflito bélico a que o Mundo assistiu. Essa amizade política teria reflexo no futebol, sendo regulares os jogos particulares entre as selecções de Portugal e Espanha, assumindo alguns deles fortes conotações políticas.

\section{CONCLUSÃO}

Durante a primeira metade do século XX construiuse claramente uma forte amizade ibérica no futebol, fruto de seis importantes factores. O primeiro, geográfico. A proximidade e isolamento geográficos de Portugal e Espanha, em relação ao resto da Europa, levaram a uma natural aproximação entre os clubes dos dois países, assente sobretudo em dois eixos geográficos e futebolísticos: Porto-Galiza (em especial Vigo) e Lisboa-Madrid-Andaluzia. Um segundo factor foi bélico, determinado pelo efeito das duas guerras mundiais, que agravaram o isolamento dos dois países, determinando um natural reforço das relações futebolísticas entre clubes e selecções de ambos pa- íses. O terceiro factor foi o apoio popular e mediático, criado pela opinião pública desportiva portuguesa (os jogos contra equipas espanholas atraiam sempre muito público) e pela imprensa desportiva, apologista dos intercâmbios futebolísticos entre Portugal e Espanha. O quarto factor seria de ordem competitivo, com as equipas portuguesas e órgãos associativos lusos a olharem para os jogos e resultados contra equipas espanholas como uma forma de medir a qualidade do futebol português, tendo certas derrotas com a Selecção de Espanha determinado mudanças organizativas no futebol português, como sucedeu em 1921 e 1934. O quinto factor foi político, com o futebol a ser utilizado para fins propagandísticos, como sucedeu logo após 1910, com o objectivo de consolidar a jovem República Portuguesa, ou nos anos 1930, para reforçar as relações entre os regimes fascistas portugueses e espanhóis, assentes nas figuras de Salazar e Franco, respectivamente. Finalmente, o sexto e último factor que contribuiu para a construção desta amizade ibérica no futebol, ao longo da primeira metade do século XX, foi o patriotismo, com cada embate frente aos espanhóis a ser visto como uma representação simbólica da luta pela independência dos portugueses frente aos espanhóis e da afirmação de Portugal como nação: cada vitória redundava em euforia popular, reforçando os discursos mediáticos sobre a regeneração nacional e sobre a grandeza de Portugal, enquanto as derrotas eram vistas como exemplos da decadência e degeneração nacional, desembocando em discursos negativos sobre a sociedade portuguesa.

\section{NOTAS}

1 Uma das vozes que pugnou por uma "Aliança Peninsular» foi o integralista António de Sousa Sardinha, que em 1922 advogava o surgimento de um «Quinto Império» (Portugal e Espanha). Isto numa época em que o general Primo de Rivera iniciava uma experiência nacionalista em Espanha, a qual poderia envolver toda a Península, situação que agradava a alguns integralistas (Barreira, 1982, 1428).
2 Reis, Ribeiro, Relações internacionais, Sporting, 9 Novembro 1937.

3 La Falange foi um partido político criado em Espanha em 1933 e a sua ideologia assentava na defesa dos valores católicos contra o perigo do marxismo e na criação de um Estado totalitário sem classes, promovendo os interesses dos trabalhadores. Durante a guerra, teve mais de dois milhões de membros. Franco decidiu entregar-lhe em 1941 a tutela do desporto e do futebol.

4 Reis, Ribeiro dos; Ornelas, Ricardo, A primeira vitória dos portugueses contra a Espanha, Diário de Notícias, 29 Novembro 1937. 


\section{BIBLIOGRAFÍA}

Barreira, Cecília (1982): "Três nótulas sobre o integralismo lusitano", in AAVV, $A$ Formação de Portugal Contemporâneo, 1900-1980, Lisboa, Revista do Instituto de Ciências Sociais.

Bromberger, C. (1993): “Allez O. M., Forza Juve - The passion for football in Marseille and Turim", in Redhead, S., The passion and the fashion, Aldershot, Avebury.

Coelho, João Nuno (2001): Portugal, a equipa de todos nós - nacionalismo, futebol e media, Porto, Edições Afrontamento.

Coelho, João Nuno; Pinheiro, Francisco (2002): A paixão do povo - história do

\section{Imprensa periódica desportiva}

Sport de Lisboa, O (Lisboa, 1915-1934)

Sporting (Porto, 1921-1953)

Sports, Os (Lisboa, 1919-1945)

Stadium (Lisboa, 1932-1951)

Tiro e Sport (Lisboa, 1904-1913) futebol em Portugal, Porto, Edições Afrontamento.

Coelho, João Nuno; Pinheiro, Francisco (2004a): A nossa selecção em 50 jogos, 1921-2004, Porto, Edições Afrontamento.

Coelho, João Nuno; Pinheiro, Francisco (2004b): "História do futebol em Portugal, 1888-2004", in Garganta, Júlio; Oliveira, José; Murad, Maurício: Futebol - de muitas cores e sabores, Porto, Campo das Letras.

Pinheiro, Francisco (2006): A Europa e Portugal na imprensa desportiva (18931945), Coimbra, MinervaCoimbra.
Teja, Ángela (2002): “Deporte y relaciones internacionales durante el fascismo en Italia", in González Aja, Teresa: Sport y autoritarismos, Madrid, Alianza Editorial.

Rosas, Fernando (1991): “A neutralidade portuguesa durante a II Guerra Mundial no quadro da política externa do Estado Novo (1935-1945)", in Torre, Hipólito, Portugal, España y Europa - Cien años de desafío (1890-1990), Mérida, Universidad Nacional de Educación a Distancia. 